among them were the observations of Thaddæus Haenke (1761-1817). His detailed work on the flora of north Bohemia brought him into prominence and led to his famous expedition to South America under the patronage of Count Sternberg. The masses of material he dispatched to Prague were later the subject of a handsome work in two volumes known as the "Reliqueæ Haenkeanæ", in the production of which the best Bohemian botanists collaborated.

The first attempt at a complete Flora of the country was that of F. W. Schmidt ("Flora Boemica"), which appeared in 1793-94. It was, however, uncritical and included plants that the author guessed would be found in naturally rich areas like the Giant's Mountains and the Bohemian Forest. A second attempt was made by Prof. Jan Novodvorský (1773-1810), but his manuscript was burnt just before he died. A third work, by J. E. Pohl (1782-1834), was also fated to remain unfinished, though two parts of his "Tentamen Flora Boemiæ" did appear in 1817. Pohl's flora was based on his own observations and on those of others which could be verified by visits to the localities where the plants grew.

Far superior was the "Flora Cechica" of the brothers J. S. and K. B. Presl. It had been completed in 1812, but was not printed until 1819. The preface was in Latin and was followed by a section in Czech, Napomenuti (reminders), in which the authors explained how they revived Czech botanical terms and also introduced new ones where needed by adapting Polish or Russian expressions to bring the subject into line with the Linnean system, which they followed in compiling the Flora. J. S. Presl, who did so much to advance the study of science among the Czech people, whereas his brother was more occupied in original investigations, particularly in connexion with the study of ferns, wrote a general text-book" of botany ("Rostlinář", 1822), which included introductory biology, plant chemistry, besides anatomy, plant physiology and what would now be styled ecology. 'The illustrations' were remarkably faithful, and some copies were handpainted by his sister. It served as the basis for later Czech botanical treatises, and most of the terms used for flowering plants are still applied to-day, but those relating to cryptogams have largely disappeared or undergone alteration.

In addition J. S. Presl wrote an elementary botany and also an advanced work, "Všeobecný Rostlinopis" (general botany) in two volumes of more than two thousand pages. It appeared in 1846, and four thousand copies were circulated, a remarkable tribute to the interest in botany shown by a small nation in the middle of last century. K. B. Presl's work reached a more international public since he wrote mostly in Latin. Fourteen of his papers are listed in the Royal Society's catalogue of scientific papers. His books include a classic on ferns, "Testamen Pterodographiæ" (1836), with beautifully executed plates, many of the species being described for the first time. It classified 117 genera, and a supplement in 1845 brought the total to 132. This was his greatest work, though he also wrote a monograph on lobelias ${ }^{3}$.

Several nobles, who were landowners in Bohemia, also encouraged the development of science. Thus, Count Malabaila Canal (1745-1826) was interested in applied science, cultivated a garden of economic plants and founded a lectureship in applied botany, the last lecturer being K. B. Presl. He encouraged the growing of sugar beet and established the first Czech factory for its extraction. He also improved fruit cultivation by introducing better grafting methods. Count Berchtold encouraged the cultivation of more potatoes, patronized contemporary botanists, and was a generous supporter of the National Museum. He wrote a standard work on the potato, and also a book on economic plants ${ }^{4}$. But the greatest botanist among the Bohemian nobles was Count Kaspar Sternberg (1761-1838), who not only supported eontemporary Czech men of science but also was himself an investigator and author of considerable merit ${ }^{5}$. Most of his seventy-four works were in German, though he refers to Czech as "our tongue" and he translated some Czech mining notes into German in his paleobotanical treatise, "Flora der Vorwelt". $\mathrm{He}$ was instrumental in founding the Bohemian National Museum in 1818, became its first president, and gave it his herbarium of 9,000 specimens, to which he added purchases from abroad and the collections sent by Czech botanists from overseas. Sternberg also appointed Palacký, the historian, to be editor of the Museum's quarterly journal, and this has since been a powerful propagator of science among the Czech nation up to the present time. His last public function was to preside over a congress of medical men and naturalists at Prague, and he took great pride in announcing the recent discoveries of Purkyne, the Presls and others, to show that the Czech nation was making its contribution to the advancement of science whatever might be the truth of Liebig's recent assertions concerning the low level of science in Austria ${ }^{6}$. the Czech National Museum, the Charles University and other institutes in Prague, and at Brno and Litomyšl in Czechoslovakia. Some works were read at the British Museum and at the library of the London School of Slavonic Studies.

${ }^{2}$ Much information relating to the development of botany in Czechoslovakia is contained in "Vývoj ceské Př́rodovťdy" (Development of

${ }^{3} \mathrm{~K}$. B. Presl's name is attached to seven species of ferns native to Britain according to G. C. Druce's "Pocket Handbook to British Plants". Riley's "Catalogue of Ferns" (London, 1841) contained "additions by C. B. Presl".

"Berchtold, "Die Kartoffeln" (Prague, 1842).

5 NATURE, 139, 1028 (1938).

' Liebio's Annalen, 25, 339 (1838).

\section{WAR-TIME NURSERY SCHOOLS}

\section{By MRS. F. A. OGDEN}

$\mathrm{S}^{\mathrm{c}}$ CHOOL nurseries are not by any means new ventures even in Great Britain, but war-time conditions are responsible for their immediate expansion and improvement. Nursery schools for the care of the 2-5 year old children were established by local authorities in many parts of England during the 1914-18 period and afterwards, but in very few cases was there accommodation adequate to the growing needs. Schools were started in an experimental sort of way, and the permissive attitude of the Board of Education seemed to encourage the lul in progress. It would have been fortunate for the country if every local education authority had been in control of sufficient nursery schools to cope with all the 2-5 year old children in 1939. When war broke out and the call for women in industry became accentuated, so the need for proper accommodation for their young families made itself felt, and war-time nurseries were speedily developed. In some centres new nursery schools were prepared or completed. In many, nursery classes were established in the junior 
schools and these brought a new low age-level of infant classes where, in difficult circumstances, children under two years of age were admitted. In more isolated places day nurseries were set up by voluntary bodies and these experiments certainly played a part in urging accommodation to meet the new needs. To release young mothers for essential war production, residential nurseries for children of less than two years of age became necessary, and maternity and child welfare committees of local authorities acting under the Ministry of Health made rapid progress in providing suitable accommodation. Grants to local authorities for establishment and maintenance by the Government were very generous, and the needs of the population of working mothers in most industrial areas was in some measure supplied. In the years 1937 and 1938 immediately preceding the War there were 107 nursery schools in Great Britain, registering an average attendance of 8,274 children less than five years of age. Thus it will be seen that a very small proportion of the population was then accommodated. In addition to further schools of this type in 1942, there were more than 1,000 day nurseries, 400 residential nurseries and 500 more in course of preparation. Nurseries of to-day can be grouped under the following heads :

(1) Nursery schools (under the authority of the ocal education committee and the Board of Educaion), day only ;

(2) War-time nursery classes (under the authority of the local education committee and the Board of ¿ducation), day only ;

(3) Residential war nurseries (under the authority of the Maternity and Child Welfare Committee and Ministry of Health), 24 hours or 6 days.

(4) Voluntary nurseries controlled by other volunbary organizations, such as the Women's Voluntary Service, Canadian Red Cross, British Red Cross, Anglo-American War Relief Fund, etc.

In day-nursery classes difficulties arising from war conditions, such as hours of work of parents on night shifts, etc., had to be met, and it became necessary to revise the hours of attendance of teaching staff in the junior schools affected. It would be impossible to pay too high a tribute to the young teachers who took voluntary duty at 6 a.m. or stayed until 8 p.m. to meet the convenience of war working mothers. Difficulties in providing equipment were met by the combined efforts of amateur craftsmen in A.R.P. posts, schoolboys in woodworking classes, W.V.S. sewing and knitting parties-and bright toys soon changed the school atmosphere and produced a delightful nursery air. Stencilled friezes of wonderful design in gay colours shut out the heavy tones of a dreary outside world; inviting rest hammocks with cosy rugs appeared; accommodation for personal hygiene was provided or multiplied ; miniature towels, toothbrushes and bright pinafores made their appearance; in other rooms dainty tables and small chairs with crockery and gaily coloured cloths were installed.

The ideal nursery school is a place of great delight. The tiny children arrive in charge of mother, father or elder one of the family at 6 a.m. or 8 a.m. A young teacher with the right feminine instincts normally takes over. With quick observation she registers tired or rested, sick or well, washed or unwashed; outdoor elothes are divested, hands and face washed, personal attention given if needed, and the child is soon absorbed in the inviting atmosphere, losing his self-interest and forgetting his little worries.
Later, tables are prepared for breakfast and four little people take their chair to a table, where after a simple grace they are soon enjoying their first meal of the day-a well-balanced, healthful breakfast.

Self-education is a great feature of the nursery training to-day. Careful direction is given, but the temptation to which mothers so often yield to 'do for' and to 'show how' is advisedly resisted. It is not unusual to see a child of three years working with a small hammer and a few nails and, without any outside help, producing a simple toy roughly put together but with a clear indication of achievement which is easily recognized; it is to the child-mind a real boat or ship complete with mast, or a bomber plane fitted with bomb racks (this is a record of actual observation). Perfection in execution is a far step, but the self-conceived idea, the attempted expression and satisfaction in completion are valuable apperceptive links for the child and valuable guide lines for the teacher. Primitive dolls in cradles or beds, gardens and hen coops indicate other lines of interest, while on one occasion a child revealed that its chief delight was in producing eo fins with tiny bodies rolled out in plasticine lying therein. When the play period is ended, the morning milk, cod liver oil or fruit juice is given, according to nurse's directions, to each child, and a period of restful attention to teacher's talk provides a physical relaxation as a counterpart to the engagement of the mental faculties. Time for lunch soon arrives and training in personal hygiene precedes the meal. The older children of four and five years are very quickly trained to help in serving and assisting the younger members of the community, showing good examples in table manners to the less advanced. The lunch is balanced on dietetic principles by the medical o.ficer and his staff, cooked by a trained woman, and is designed to give all the nourishment required at the proper age. After the lunch, while the children have a period of free play, with toys indoors, or in the sunshine out of doors, the rest hammocks are disposed on the floor and tired little heads and hands are soon resting on them. Even here the teacher's watchful eye must be on the alert. Restlessness must be carefully noted and investigations made which may result in the temporary attention of the teacher or in the calling of a nurse or even a doctor. Much can be learned of a child's temperament and condition by a careful observation of its resting period.

Observation of the child's play interest and activities is a most valuable index to the understanding teacher of his moral and mental tendencies and his growing character. Stimulation or discouragement at the right moment may help to attain the proper balance which results in a normal social attitude.

The importance of early training in regular personal habits cannot be over-estimated. The instincts of the primitive peoples are sometimes reflected in child behaviour. The wolfing of food at irregular times, attacks on weaker children which seem sometimes to have no object but subjugation, the acquisition of coveted toys by force, the destructive craze, or the satisfaction resulting from obvious discomfort in others, are examples of under-developed and uneducated reaction. Careful training in proper behaviour and regular habits with a view to the comfort and happiness of the community is an aim of nursery school life. Self-control is induced by insisting on the proper time for personal hygiene. This may have far-reaching consequences and provide a sound basis for character formation which will react to 
the individual and communal benefit in later years. From the point of view of physical health, conditions in war-time nurseries are more propitious to sound development than those in 90 per cent of the homes from which the children are drawn. The balanced diet; the opportunity for fresh air and play; regulated sleep; the use of educational toys; the advantage of communal interests and choice of companionship; the opportunity for free expression in the choice of toys are all advantages which could not be supplied in the great majority of the homes from which the children have come.

The teacher who is suitable for nursery school work has special qualifications natural to her character. With a good educational background she develops the capacity to make herself understood by small children. Her voice is gentle and clear. If she has imagination she can make the nursery stories live so that they will remain as an influence with the young minds long after school days. The ability to draw, with a good sense of colour, to play simple nursery songs and to sing lullabies is a very desirable addition to her qualifications. Above all, she should be healthy with a developing maternal instinct of her own, finding its early expression in a communal way and giving sympathetic understanding and love to the children under her care. In the last two years there has been great competition to enter colleges for nursery school work, and this should have made it possible for the most suitable young people to be selected. It is therefore a well-founded hope that future years will provide a sufficient staff of the right quality for the nursery schools which we hope to see in abundance in a post-war period. At the moment the teaching staff of war-time nurseries is deplorably inadequate. A considerable proportion of it consists of young girls leaving school at the age of fourteen who with a short course of six weeks training have loyally undertaken the responsibility. A large proportion also consists of older mothers whose families are grown up and who may have had little contact with young life in the last twenty-five years. Nevertheless they too have loyally placed their service at the call of the country's need, and the valuable maternal instinct which has been the foundation of a short course of training lasting 4-6 weeks has of necessity had to be their only training for this very responsible and important work.

Records of progress show that physically and mentally the children in these schools have received great benefit, and the contribution to the stamina and resource of the nation cannot be properly assessed at this juncture. It may be, however, that out of this war-time experience will grow a permanent and complete schene for the proper care of young life.

\section{OBITUARIES}

\section{Prof. F. D. Adams, F.R.S.}

Frank Dawson Adams, emeritus Logan professor of geology and vice-principal of McGill University, Montreal, died on December 27 at the age of eightythree. He was one of the great pioneers in the study of the Precambrian rocks of Canada and in the field of experimental geology. Born in Montreal on September 17, 1859, Adams was educated at McGill University, where he came under the influence of Sir
William Dawson, his great predecessor in the Logan chair. After a year of postgraduate study at Yale, he was appointed an assistant on the Geological Survey of Canada: in this service he continued until 1889, when he resigned to become lecturer in geology at MeGill University, succeeding to the chair four years later.

Adams's first field investigations were devoted to a study of the character and relations of the large anorthosite bodies lying near the border of the Canadian Shield, north of the St. Lawrence River, within and close to Logan's original Laurentian area. This group of rocks, in places exhibiting a distinct foliation, was supposed by Logan to form a stratified series-his Upper Laurentian-distinct from, and reposing on the Grenville Series. Adams at this time was well equipped for his task-he was a skilled petrographer versed in the new methods of the science, for he had already studied under Rosenbusch -and the detailed mapping he began in 1883 soon brought results of the first importance. He conclusively demonstrated the igneous nature of the partly foliated anorthosites, revealed the aqueous origin of an important group of highly metamorphic garnet gneisses within the Grenville Series and was thus led to a fundamental revision of the classification of the Precambrian in the St. Lawrence area. Some of these results were published as a dissertation at Heidelberg, where he had continued his researches under Rosenbusch during several summer semesters. Meantime, the epoch-making investigations of A. C. Lawson on the Laurentian succession in the Lake Superior region 800 miles westward had been published, and led Adams, on the completion of his researches in Quebec, to a detailed survey of a large area of the Grenville Series in Eastern Ontario in order to provide a satisfactory knowledge of the Precambrian succession in Eastern Canada. The region selected-the Haliburton-Bancroft areawas geologically almost a terra incognita, of which no topographic survey had been made. The field work, in which he was later joined by A. E. Barlow, occupied eight years, the results being published in a memoir in 1910 .

These investigations form a classic study on the Canadian Shield and placed Adams in the front rank of petrologists. The phases of metamorphism and varied constitution of the underlying Grenville Series and the character and relations of the succeeding Laurentian granite 'batholiths' were brilliantly demonstrated, while the beautiful maps which accompanied the memoir have furnished the type material for all later discussions on concordant intrusives in folded sediments. Among the more striking petrographic results was the discovery of great bodies of nepheline syenite about the borders of the Laurentian granites. These alkali rocks presented many remarkable variations in composition, and some varieties, being rich in corundum, were afterwards made the basis of an extensive industry for the exploitation of this mineral.

Adams's ripe experience and acknowledged authority in the field of Precambrian research led to his appointment to several international committees to investigate critical localities and to report on the correlation and nomenclature to be adopted for the Precambrian areas on both sides of the Canadian boundary.

The second great field of endeavour in Adams's career was his study of the experimental behaviour of rocks under differential stress. His keen interest 